
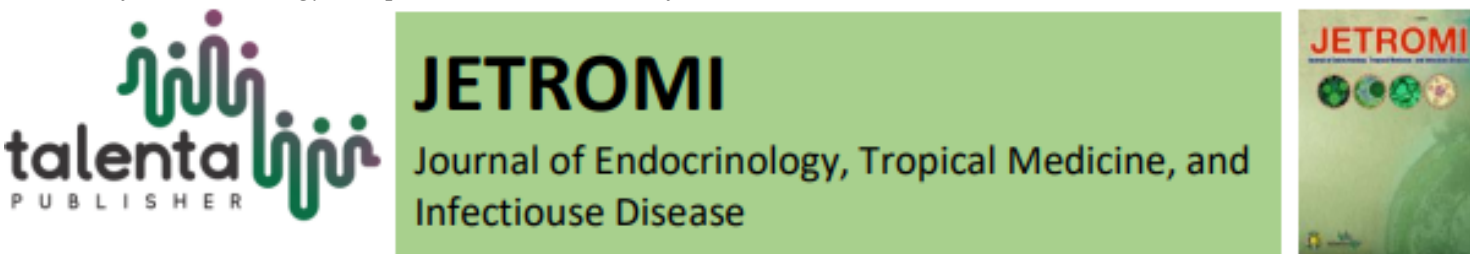

\title{
The Effect of Fasting Ramadhan on Malondialdehyde Levels Stress Oxidative Parameter in Obese Patient
}

\author{
Septi Nina Maria Ginting ${ }^{1}$, Melati Silvanni Nasution ${ }^{2}$ \\ ${ }^{1}$ Department of Internal Medicine, Metabolic Endocrinology and Diabetes Division of Universitas \\ Sumatra Utara
}

\begin{abstract}
Obesity induces the formation of reactive oxygen species (ROS) which is produce oxidative stress that is involved in various pathological processes such as malondialdehyde (MDA) which is a highly toxic molecule. In Indonesia, Muslims are fasting for 13-14 hours during Ramadhan. Researchers interested in conducting research on the effect of fasting Ramadhan on oxidative stress (MDA levels) in individuals with obesity. This research is a prospective cohort. The study was held on March - May 2019 at Outpatient Clinic Endocrinology of RSUP. H. Adam Malik Medan with the approval of the FK USU Research Ethics Commission and according to the criteria of inclusion and exclusion. The Data is analyzed by using the SPPS program where $p<0.05$ is considered significant. The results of the study obtained a meaningful decline in the level of MDA before and after the fasting of Ramadhan ( $<<0.001)$. The median rate of MDA before Ramadhan was $4.88 \mathrm{nmol} / \mathrm{ml}(1.68-101,5 \mathrm{nmol} / \mathrm{ml})$ and after Ramadhan fasting the median rate of MDA became $3.96 \mathrm{nmol} / \mathrm{ml}(0.97-92,20 \mathrm{nmol} / \mathrm{ml})$. There was decreased of oxidative stress parameter MDA levels after Ramadhan fasting in obese patients.
\end{abstract}

Keywords: Ramadhan fasting, Obesity, MDA, ROS

\begin{abstract}
Abstrak. Obesitas menginduksi pembentukan reactive oxygen species (ROS) yang kemudian menghasilkan stres oksidatif yang terlibat pada berbagai proses patologis, seperti malondialdehyd (MDA) yang merupakan molekul yang sangat toksik. Di Indonesia, Muslim berpuasa selama 13-14 jam selama Ramadhan.. Peneliti tertarik untuk melakukan penelitian mengenai efek puasa ramadhan terhadap stres oksidatif (kadar MDA) pada individu dengan obesitas. Penelitian ini merupakan kohort prospektif.Penelitian dilaksanakan Maret - Mei 2019 di Poliklinik Rawat Jalan Endokrin RSUP.H. Adam Malik Medan dengan persetujuan Komisi Etik Penelitian FK USU dan sesuai kriteria inklusi dan eksklusi. Data dianalisis dengan menggunakan program SPPS di mana $p<0,05$ dianggap signifikan. Dari hasil penelitian didapatkan penurunan bermakna kadar MDA sebelum dan setelah puasa Ramadhan ( $p<0,001)$. Median kadar MDA sebelum puasa Ramadhan adalah 4,88 $\mathrm{nmol} / \mathrm{ml}(1,68-101,5 \mathrm{~mol} / \mathrm{ml})$ dan setelah puasa Ramadhan median kadar MDA menjadi 3,96 $\mathrm{nmol} / \mathrm{ml}(0,97-92,20 \mathrm{nmol} / \mathrm{ml})$. Didapatkan penurunan parameter stres oksidatif MDA setelah puasa Ramadhan pada pasien Obesitas.
\end{abstract}

Kata kunci: Puasa-Ramadhan, Obesitas, MDA, ROS

Received 11 April 2020 | Revised 22 April 2020 | Accepted 11 May 2020

\footnotetext{
*Corresponding author at: Please enter address of author's affiliation, including faculty, department, university, address, city and country
}

E-mail address: septinina.ginting@gmail.com 


\section{Introduction}

Obesity is one of the diseases that is a problem of the world nowadays where it is a complex multifactorial disease. Globally, there were 1.9 billion and 609 million obese and overweight suffers in 2015, responsively reaching $39 \%$ of the world's population. In Southeast Asia prevalence of obesity also increased from $1.7 \%$ (1980) to $6.2 \%$ (2015) [1]. Obesity is also a serious problem in Indonesia with a prevalence of $23.1 \%$ of population [2]. Obesity is a chronic disease that is marked by an increase in body fat which not only functions as storage of triglycerides but also produces bioactive substances such as adipokines, IL-6 and leptin. Adipokines induces the formation of reactive oxygen species (ROS) which is produce oxidative stress that is involved in various pathological processes [3]. Some of the known oxidative stress biomarkers are malondialdehyde (MDA) which is a highly toxic molecule and its interactions with DNA and proteins can be carcinogenic, mutagenic and atherogenic. To minimize the effects of these free radicals there is an an antioxidant complement system that protecs organism by preventing by preventing the formation of free radicals such as glutathione peroxidase (GSH-Px), glutathione-S transferase (GST), superoxide dismutase (SOD), catalase (CAT), vitamin A, E and C [3].

Ramadhan fasting is one of the pillars of Islam that must be implemented by every Muslim around the world for a full month during the month of Ramadhan (Hijri calendar). In Indonesia, Muslims are fasting for 13-14 hours. In addition to holding food and drinking, during fasting is also forbidden to smoke, sexual intercourse and is encouraged to resist emotions [4]. Fasting or Intermittent Fasting (IF) may decrease inflammation and the oxidative stess via an autophagyi activation. IF lowers insulin levels in circulation and fasting blood sugar levels, parallel to the increased concentration of growth hormone and insulin sensitivity. IF is an effect on the cardiovascular system by lowering blood pressure, cholesterol concentration, LDL, and triglycerides. IF also relates to weight loss and abdominal fat so as to fix the metabolic marker significantly. The effect of Ramadhan intermittent fasting (RIF) on oxidative stress is still unclear and there is a difference among some research based on the background above the researchers interested in conducting research on the effect of fasting Ramadhan on oxidative stress MDA levels in individuals with obesity [5].

\section{Methods}

The study design was a prospective cohort observational study with the independent variable being Ramadhan fasting and the dependent variable was lipid profile and MDA levels. The study was conducted at the endocrine outpatient clinic at Haji Adam Malik General Hospital Medan from March to May 2019 with a total sample of 30 patients according to inclusion and exclusion criteria. The sample collection in this study was carried out using the purposive sampling method. Every patient who came to Haji Adam Malik General Hospital who was obese in accordance with the study criteria was taken as a sample. After fulfilling the study 
criteria, the patient fills out the consent letter after receiving an explanation. The study sample was chosen consecutively for patients who met the criteria, until the required number of samples were met. Then anthropometric examination will be carried out by measuring body weight, height, BMI, waist size, hip size and examination of lipid profiles (total cholesterol, Low Density Lipoprotein cholesterol (LDL-C), and High Density Lipoprotein cholesterol (HDL-C)) and MDA. The relationship between the results of atropometric examination, hemodynamics, lipid profile and MDA levels before and after Ramadhan fasting in obese patients will be analyzed using the Wilcoxon test.

While the relations between changes in BMI with lipid profile levels and MDA will be analyzed using the Spearman correlation. All analyzes were guided by a two-way hypothesis test and had a $95 \%$ CI. A p value of $\leq 0.05$ was considered statistically significant. Analysis and presentation of data used statistical analysis with the Stastical Product and Service Solution (SPSS) 22.0 software for windows. To assess whether the sample is in a normal distribution or not using the Shapiro-Wilk test, if the number of samples is below fifty. Data is prepared in the form of mean \pm standard deviation if the data distribution is normal, if not the normal distribution is presented in the form of a median (min-max). Acceptance criteria include subjects aged 40-65 years, both men and women who fast during the month of Ramadhan (13-14 hours) and have 2 meals (30 minutes before sunrise and 30 minutes before sunset), obese patients (BMI $\geq 25 \mathrm{~kg} / \mathrm{m} 2$ ), receive information and consent to participation is voluntary and written to undergo a known physical and laboratory examination and approved by the health research ethics committee, and does not include rejection criteria such as patients taking long-term drugs (hormonal drugs, corticosteroids, anti-diabetic drugs, cholesterol-lowering drugs), patients with infections or a history of previous infections, patients with myocardial infarction, inflammatory arthritis and malignancy, sufferers of systemic disease ( such as Diabetes Mellitus, Chronic Kidney Disease) and hormonal diseases (thyroid disease, growth hormone disorders, reproductive disorders and adrenal hormone disorders), patients who consumed alcohol during the study period, patients who took drugs or herbs for the purpose of losing weight or other dietary methods, patients were not cooperative as well as pregnant patients.

\section{Result}

\subsection{Characteristics of research subjects}

A total of 30 obese subjects who met the inclusion and exclusion criteria participated in this study (table 1). The mean systolic blood pressure was $120.8(111.6-130) \mathrm{mmHg}$. The mean diastolic blood pressure in the study subjects was $82.4(72.6-92.2) \mathrm{mmHg}$. The median BMI value in this study was $29.2(25.2-42.5) \mathrm{kg} / \mathrm{m} 2$. The mean waist size is $100.9(87.4-114.4)$ $\mathrm{cm}$, the mean hip size is $110.3(99.5-121.1) \mathrm{cm}$. The median ratio of waist and hip size is 1.03 (0.92-1.08). The mean total cholesterol level was 199.7 (165.3 - 234.1) $\mathrm{mg} / \mathrm{dL}$, the 
mean HDL level was 49.4 (41.2 - 57.6) $\mathrm{mg} / \mathrm{dL}$, the average LDL level was 130.1(101.7 $158.5) \mathrm{mg} / \mathrm{dL}$. The mean HDL / total cholesterol ratio was $0.26(0.19-0.33)$. Median MDA level of $4.88(1.68-101.5) \mathrm{nmol} / \mathrm{mL}$.

Table 1. Characteristics of Research Subjects

\begin{tabular}{|c|c|}
\hline Characteristics & $\begin{array}{c}\mathbf{n}=\mathbf{3 0} \\
\text { med (min-max) }\end{array}$ \\
\hline \multicolumn{2}{|l|}{ Gender } \\
\hline Male & $27(90 \%)$ \\
\hline Female & $3(10 \%)$ \\
\hline Age $(\text { year })^{\mathrm{a}}$ & $27.2(23.3-31.1)$ \\
\hline Height $(\mathrm{cm})^{\mathrm{a}}$ & $170,6(163.9-177.3)$ \\
\hline Body weight $(\mathrm{kg})^{\mathrm{a}}$ & $90.8(72.2-109.4)$ \\
\hline $\operatorname{BMI}\left(\mathrm{kg} / \mathrm{m}^{2}\right)^{\mathrm{b}}$ & $29.2(25.2-42.5)$ \\
\hline Waist size $(\mathrm{cm})^{\mathrm{a}}$ & $100.9(87.4-114.4)$ \\
\hline Hip size $(\mathrm{cm})^{\mathrm{a}}$ & $110.3(99.5-121.1)$ \\
\hline Waist/hip ratio ${ }^{\mathrm{b}}$ & $1.03(0.92-1.08)$ \\
\hline $\mathrm{SBP}(\mathrm{mmHg})^{\mathrm{a}}$ & $120.8(111.6-130)$ \\
\hline $\mathrm{DBP}(\mathrm{mmHg})^{\mathrm{a}}$ & $82.4(72.6-92.2)$ \\
\hline $\mathrm{TC}(\mathrm{mg} / \mathrm{dL})^{\mathrm{a}}$ & $199.7(165.3-234.1)$ \\
\hline $\mathrm{HDL}-\mathrm{C}(\mathrm{mg} / \mathrm{dL})^{\mathrm{a}}$ & $49.4(41.2-57.6)$ \\
\hline $\mathrm{LDL}-\mathrm{C}(\mathrm{mg} / \mathrm{dL})^{\mathrm{a}}$ & $130.1(101.7-158.5)$ \\
\hline HDL/TC ratio & $0.26(0.19-0.33)$ \\
\hline $\operatorname{MDA}(\mathrm{nmol} / \mathrm{mL})$ & $4.88(1.68-101.5)$ \\
\hline
\end{tabular}

BMI: body mass index; SBP : Systolic Blood Pressure DBP : Diastolic Blood Pressure BMI: body mass index; TC: total cholesterol; HDL-C: High Density Lipoprotein cholesterol, LDL-C Low Density Lipoprotein cholesterol; MDA: malondialdehyde

\subsection{Changes in Hemodynamic and Anthropometric Parameters Before and After}

\section{Ramadhan Fasting in Research Subjects}

Changes in hemodynamic and anthropometric parameters before and after Ramadhan fasting can be seen in table 2 .

Table 2. Changes in Hemodynamic and Anthropometric Parameters Before and After Ramadhan Fasting in Research Subjects

\begin{tabular}{|c|c|c|c|}
\hline Characteristic & $\begin{array}{c}\mathbf{p 1} \\
\operatorname{med}(\min -\max )\end{array}$ & $\begin{array}{c}\mathbf{p 2} \\
\operatorname{med}(\min -\max )\end{array}$ & $\mathbf{P}$ \\
\hline $\mathrm{SBP}(\mathrm{mmHg})^{\mathrm{a}}$ & $120.8(111.6-130)$ & $119.7(108.4-131)$ & 0.475 \\
\hline $\mathrm{DBP}(\mathrm{mmHg})^{\mathrm{a}}$ & $82.4(72.6-92.2)$ & $81.1(70.6-91.6)$ & 0.417 \\
\hline Body weight $(\mathrm{kg})^{\mathrm{a}}$ & $90.8(72.2-109.4)$ & $89.4(70.9-107.9)$ & $0.001 * *$ \\
\hline $\operatorname{BMI}\left(\mathrm{kg} / \mathrm{m}^{2}\right)^{\mathrm{b}}$ & $29.2(25.2-42.5)$ & $28.8(25.1-42.0)$ & $0.001 * *$ \\
\hline Waist size $(\mathrm{cm})^{\mathrm{a}}$ & $100.9(87.4-114.4)$ & $98.7(86.7-110.7)$ & $0.016 *$ \\
\hline Hip size $(\mathrm{cm})^{\mathrm{a}}$ & $110.3(99.5-121.1)$ & $108.3(98.1-118.5)$ & $0.005^{*}$ \\
\hline Waist/Hip ratio ${ }^{\mathrm{b}}$ & $1.03(0.92-1.08)$ & $0.92(0.80-1.01)$ & $0.001 * *$ \\
\hline
\end{tabular}

There were significant differences in body weight and BMI of research subjects before and after Ramadhan fasting ( $\mathrm{p}<0.001$ and $\mathrm{p}<0.05)$ (Table 2). where the mean weight of the study subjects before Ramadhan fasting was 90.8 (72.2-109.4) $\mathrm{kg}$ and after Ramadhan fasting 
becomes 89,4 (70.9-107.9). From BMI, the median BMI of research subjects before Ramadhan fasting was $29.2(25.2-42.5) \mathrm{kg} / \mathrm{m} 2$ and after Ramadhan fasting it became 28.8 (25.1-42.0) kg / $\mathrm{m} 2$. There was a statistically significant weight loss and BMI after the fasting of Ramadhan.

Waist size, hip size, and waist / hip size ratio of study subjects before and after Ramadhan fasting also showed a significant decrease. The mean waist size of the study subjects before Ramadhan fasting was 100.9 (87.4 - 114.4) cm and after Ramadhan fasting it became 98.7 (86.7 - 110.7) $(\mathrm{p}=0.016)$. The mean hip size of the study subjects before Ramadhan fasting was $110.3(99.5-121.1) \mathrm{cm}$ changed to $108,3(98.1-118.5)(\mathrm{p}=0.005)$ after Ramadhan fasting. The median waist-to-hip size ratio of study subjects before Ramadhan fasting was 1.03 (0.92-1.08) and after Ramadhan fasting to $0.92(0.80-1.01)(\mathrm{p}<0.001)$

\subsection{Changes in Laboratory Parameters Before and After Ramadhan Fasting}

Changes in laboratory parameters before and after Ramadhan can be seen in table 3 .

Table 3. Changes in Lipid Profile and MDA Levels Before and After Ramadhan Fasting in Research Subjects

\begin{tabular}{|c|c|c|c|}
\hline Characteristic & $\begin{array}{c}\text { P1 } \\
\text { med (min-max) }\end{array}$ & $\begin{array}{c}\text { P2 } \\
\operatorname{med}(\min -\max )\end{array}$ & $\mathbf{P}$ \\
\hline $\mathrm{TC}(\mathrm{mg} / \mathrm{dL})^{\mathrm{a}}$ & $199.7(165.3-233.8)$ & $185.5(150.3-220.2)$ & $0.001 *$ \\
\hline HDL-C $(\mathrm{mg} / \mathrm{dL})^{\mathrm{a}}$ & $49.4(41.2-57.6)$ & $52.5(44-61)$ & $0.049 *$ \\
\hline LDL-C $(\mathrm{mg} / \mathrm{dL})^{\mathrm{a}}$ & $130.1(101.7-158.5)$ & $129.0(96.1-161.9)$ & 0.729 \\
\hline HDL-C /TC ratio & $0.26(0.19-0.33)$ & $0.30(0.21-0.39)$ & $0.021 *$ \\
\hline $\mathrm{MDA}^{\mathrm{b}}$ & $4.88(1.68-101.5)$ & $3.96(0.97-92.2)$ & $0.001 * *$ \\
\hline $\begin{array}{l}\text { TC:Total Cholestero } \\
\text { Cholesterol; MDA : } \\
\text { distribution ; median } \\
* \text { p }<0.05 ; * * p<0.001\end{array}$ & $\begin{array}{l}\text { C: High Density Lipop } \\
\text { aldehyde; a normal dist } \\
\text { ax); Wilcoxon test } \\
\text { re Ramadhan fasting; }\end{array}$ & $\begin{array}{l}\text { holesterol; LDL-C : Lo } \\
\text { 1; mean deviation; paire } \\
\text { Ramadhan fasting }\end{array}$ & $\begin{array}{l}\text { ensity Lip } \\
\text { est }^{\mathrm{b} a} \text { abnor }\end{array}$ \\
\hline
\end{tabular}

Significant differences in total cholesterol, HDL-C, and HDL-C/ cholesterol total ratios were observed before and after Ramadhan fasting ( $\mathrm{p}<0.001 ; \mathrm{p}=0.049 ; \mathrm{p}=0.021$ ) (table 3 ). The mean total cholesterol level of the study subjects before Ramadhan fasting was 199.7 (165.3 233.8) $\mathrm{mg} / \mathrm{dL}$ and after Ramadhan fasting it became 185.5 (150.3 - 220.2) $\mathrm{mg} / \mathrm{dL}$. The mean HDL-C level of the study subjects before Ramadhan fasting was 49.4 (41.2 - 57.6) $\mathrm{mg} / \mathrm{dL}$ and after Ramadhan fasting it became 52.5 (44 - 61) mg / dl. The mean HDL-cholesterol ratio of the total study subjects before Ramadhan fasting was $0.26(0.19-0.33)$ and after Ramadhan fasting it became $0.30(0.21-0.39)$.

A significant decrease in MDA levels was found before and after Ramadhan fasting ( $\mathrm{p}<0.001)$. The median MDA level before Ramadhan fasting is 4.88 (1.68-101.5) and after Ramadhan fasting the median MDA level is 3.96 (0.97-92.20). 


\subsection{Differences in Anthropometric Changes and Laboratory Parameters Before and After Ramadhan Fasting by Tarawih Category}

Differences in anthropometric changes and laboratory parameters before and after Ramadhan fasting based on tarawih categories can be seen in table 4 .

Table 4. Differences in anthropometric changes and laboratory parameters before and after Ramadhan fasting based on tarawih categories

\begin{tabular}{|c|c|c|c|c|c|c|c|c|c|}
\hline \multirow{2}{*}{$\begin{array}{l}\text { Characte } \\
\text { ristic }\end{array}$} & \multicolumn{3}{|c|}{$<15$ days } & \multicolumn{5}{|c|}{$>15$ days } & \multirow{2}{*}{$\Delta p$} \\
\hline & $\begin{array}{c}\text { Before } \\
\text { Med (min-max) }\end{array}$ & $\begin{array}{c}\text { After } \\
\text { Med (min-max) }\end{array}$ & $\Delta$ & P1 & $\begin{array}{c}\text { Before } \\
\text { Med (min-max) }\end{array}$ & $\begin{array}{l}\text { After } \\
\text { Med (min-max) }\end{array}$ & $\Delta$ & P2 & \\
\hline $\begin{array}{l}\text { BW } \\
(\mathrm{kg})^{\mathrm{a}}\end{array}$ & $\begin{array}{c}93.4 \\
(73.4-113.4)\end{array}$ & $\begin{array}{c}92.4 \\
(72.2-112.6)\end{array}$ & -1.03 & $0.026^{*}$ & $\begin{array}{c}88.2 \\
(70.9-105.5)\end{array}$ & $\begin{array}{c}86.3 \\
(69.6-103)\end{array}$ & -1.93 & $0.001 * *$ & 0.088 \\
\hline $\begin{array}{l}\mathrm{BMI} \\
\left(\mathrm{kg} / \mathrm{m}^{2}\right)^{\mathrm{a}}\end{array}$ & $\begin{array}{c}31.6 \pm 5.7 \\
(25.9-37.3\end{array}$ & $\begin{array}{c}31.3 \\
(25.5-37.1)\end{array}$ & -0.35 & $0.033^{*}$ & $\begin{array}{c}30.4 \\
(26.1-34.7)\end{array}$ & $\begin{array}{c}29.8 \\
(25.5-34)\end{array}$ & 0.68 & $0.001^{* *}$ & 0.939 \\
\hline $\begin{array}{l}\text { Waist size } \\
(\mathrm{cm})^{\mathrm{a}}\end{array}$ & $\begin{array}{c}102.2 \\
(86.7-117.7)\end{array}$ & $\begin{array}{c}100.0 \\
(86.1-113.9)\end{array}$ & -2.2 & 0.147 & $\begin{array}{c}99.6 \\
(88.1-111.1)\end{array}$ & $\begin{array}{c}97.5 \\
(87.4-107.6)\end{array}$ & -2.1 & $0.039^{*}$ & 0.530 \\
\hline $\begin{array}{l}\text { Hip size } \\
(\mathrm{cm})^{\mathrm{a}}\end{array}$ & $\begin{array}{c}110.7 \\
(98.9-122.5)\end{array}$ & $\begin{array}{c}108.2 \\
(97-119.4)\end{array}$ & -2.5 & $0.028 *$ & $\begin{array}{c}109.9 \\
(99.8-120)\end{array}$ & $\begin{array}{c}108.3 \\
(98.7-117.9)\end{array}$ & -1.6 & 0.102 & 0.077 \\
\hline $\begin{array}{l}\text { TC } \\
(\mathrm{mg} / \mathrm{dL})^{\mathrm{a}}\end{array}$ & $\begin{array}{c}200.6 \\
(173-228.2)\end{array}$ & $\begin{array}{c}190.2 \\
(166.5-213.9)\end{array}$ & -10.4 & $0.021 *$ & $\begin{array}{c}198.9 \\
(157.7-240.1)\end{array}$ & $\begin{array}{c}180.7 \\
(136.5-224.9)\end{array}$ & 18.1 & $0.019^{*}$ & 0.339 \\
\hline $\begin{array}{l}\mathrm{HDL} C \mathrm{C} \\
(\mathrm{mg} / \mathrm{dL})^{\mathrm{a}}\end{array}$ & $\begin{array}{c}50.5 \\
(44-57)\end{array}$ & $\begin{array}{c}52.9 \\
(45.4-60.4)\end{array}$ & 2.3 & 0.075 & $\begin{array}{c}48.3 \\
(38.6-58)\end{array}$ & $\begin{array}{c}52.1 \\
(42.4-61.8)\end{array}$ & 3.8 & 0.192 & 0.634 \\
\hline $\begin{array}{l}\text { LDL-C } \\
(\mathrm{mg} / \mathrm{dL})^{\mathrm{a}}\end{array}$ & $\begin{array}{c}131.9 \\
(109.8-154)\end{array}$ & $\begin{array}{c}131.0 \\
(107.1-154.9)\end{array}$ & -0.9 & 0.769 & $\begin{array}{c}128.3 \\
(94.1-162.5)\end{array}$ & $\begin{array}{c}127.1 \\
(86.3-167.9)\end{array}$ & -1.2 & 0.826 & 0.917 \\
\hline $\begin{array}{l}\text { MDA } \\
(\mathrm{nmoL} / \mathrm{mL})^{\mathrm{b}}\end{array}$ & $\begin{array}{c}3.92 \\
(2.31-101.5)\end{array}$ & $\begin{array}{c}3.45 \\
(1.97-92.2)\end{array}$ & -0.71 & $0.001 *$ & $\begin{array}{c}5.3 \\
(1.68-100.9)\end{array}$ & $\begin{array}{c}4.7 \\
(0.97-71.07)\end{array}$ & -0.97 & $0.001 *$ & 0.171 \\
\hline
\end{tabular}

BW: body weight; Lipoprotein Cholesterol; MDA : Malondialdehyde;

a normal distribution; mean deviation; paired t test; ${ }^{\text {a a }}$ abnormal distribution ; median (min-max); Wilcoxon test; P1 before Ramadhan fasting; P2 after Ramadhan fasting; $\Delta$ p: P1 vs P2

$* \mathrm{p}<0.05 ; * \mathrm{*}<0.001 ; \mathrm{P} 1$ before Ramadhan fasting; P2 after Ramadhan fasting

Significant differences in body weight were found before and after Ramadhan fasting both in groups with tarawih less than 15 days and in the tarawih group for more than 15 days $(p=0.026$ vs $\mathrm{p}<0.001$ ). We found a higher weight loss in the group with tarawih more than 15 days compared to the group with tarawih less than 15 days $(1,93(0.83-3.03)$ vs $1.03(0.57)-2.63)$. but this difference was not statistically significant $(\mathrm{p}=0.088)$.

Significant differences in body mass index were found before and after Ramadhan fasting both in groups with tarawih less than 15 days and in the tarawih group for more than 15 days $(\mathrm{p}=$ 0.033 vs $\mathrm{p}<0.001$ ). A decrease in body mass index was found to be higher in the group with tarawih more than 15 days compared to the group with tarawih for less than 15 days $(0,68(0.3-$ $1.06)$ vs. $0,35(0.22-0.92)$, but this difference was not statistically significant $(\mathrm{p}=0.939)$.

Significant differences in waist size before and after Ramadhan fasting were found in groups with tarawih for more than 15 days, but no significant differences in waist size in the tarawih group were less than 15 days ( $p=0.039$ vs $p=0.147$ ). The decrease in waist size was found to be higher in the group with tarawih less than 15 days compared to the group with tarawih for more than 15 days $2.2(3.4-7.8)$ vs $2,1(1.4-5.6)$, but this difference was not statistically significant $(\mathrm{p}=0.530)$.

Significant differences were found in total cholesterol before and after Ramadhan fasting both in groups with tarawih less than 15 days and in the tarawih group for more than 15 days $(\mathrm{p}=$ 0.021 vs $p=0.019$ ). The decrease in total cholesterol was found to be higher in the group with 
tarawih more than 15 days compared to the group with tarawih for less than 15 days 18.1 (8.4 44.6) vs $10.4(5.1-25.9)$. but this difference was not statistically significant $(\mathrm{p}=0.339)$.

No significant differences were found in HDL before and after Ramadhan fasting both in groups with tarawih less than 15 days and in the tarawih group for more than 15 days $(\mathrm{p}=0.075 \mathrm{vs} p=$ 0.192). The increase in HDL was found to be higher in the group with tarawih more than 15 days compared to the group with tarawih for less than 15 days: $2.3(2.4-7)$ vs 3.8 ( 7 - 14.6), but this difference was not statistically significant $(\mathrm{p}=0.634)$.

No significant differences were found in LDL levels before and after Ramadhan fasting both in groups with tarawih less than 15 days and in the tarawih group for more than 15 days $(p=0.769$ vs $p=0.826$ ). The decrease in LDL levels was found to be higher in the group with tarawih more than 15 days compared to the group with tarawih for less than 15 days: 0.9 vs 1,2.

Significant differences were found in MDA levels before and after Ramadhan fasting both in groups with tarawih less than 15 days and in the tarawih group for more than 15 days ( $p$ $<0.001)$. The decrease in MDA levels was found to be higher in the group with tarawih more than 150 days compared to the group with tarawih for less than 15 days: 0.97 vs 0.71 , but this difference was not statistically significant $(\mathrm{p}=0.171)$

\subsection{Correlation of BMI Change with Lipid Profile and MDA}

No correlation was found with changes in BMI and the relation in lipid profile. and MDA

(Table 5)

Table 5. Correlation of BMI Change with Lipid Profile and MDA

\begin{tabular}{ccc}
\hline Variabel & BMI Changes & $\mathrm{P}$ \\
& $\mathrm{R}$ & 0.348 \\
TC changes & 0.178 & 0.819 \\
HDL-C Changes & 0.044 & 0.785 \\
LDL-C Changes & -0.052 & 0.456 \\
MDA Changes & 0.141 & \\
\hline *Spearman Correlation & & \\
TC: total cholesterol; HDL-C: High Density Lipoprotein cholesterol, LDL-C: Low Density Lipoprotein cholesterol; \\
MDA: malondialdehyde
\end{tabular}

\subsection{Correlation of MDA Change with Lipid Profile}

From the research. it was found that there was no correlation between changes in MDA and changes in lipid profile (Table 6)

Table 6. Correlation of Changes in MDA with Changes in Lipid Profile

\begin{tabular}{lcc}
\hline \multicolumn{1}{c}{ Spearman Correlation } & MDA Changes & \\
& $\mathrm{R}$ & $\mathrm{P}$ \\
\hline TC & 0.022 & 0.906 \\
HDL C & -0.094 & 0.620 \\
LDL C & 0.150 & 0.428 \\
\hline
\end{tabular}

*Spearman Correlation 
TC: total cholesterol; HDL-C: High Density Lipoprotein cholesterol, LDL-C: Low Density Lipoprotein cholesterol; MDA: malondialdehyde

\section{Discussion}

Obesity is a disease that's become a global problem today. Increased prevalence of obesity from year to year is accompanied by an increased incidence of diseases where obesity is a risk factor, such as heart disease, diabetes, and cancer [1]. Obesity occurs as a result of an imbalance in energy intake and expenditure characterized by a BMI $\geq 25 \mathrm{~kg} / \mathrm{m} 2$ [6]. In obesity there can be disruption in the regulation of fatty acids which will increase triglyceride and ester cholesterol levels so that obese people are more likely to have an increase in blood triglycerides, LDL cholesterol and decreased HDL cholesterol [7]. Obesity is associated with high calorie intake, which causes an increase in blood sugar and free fatty acids in the circulation. Lipids are one of the most sensitive molecules to free radical attack which can form lipid peroxide. Lipid peroxidation is a reaction that occurs between free radicals and polyunsaturated fatty acids. The final product of lipid peroxidation is MDA, and is usually used as a biological biomarker of lipid peroxidation to assess oxidative stress and free radicals [8]. Ramadhan fasting / Ramadhan intermittent fasting (RIF) is a unique dietary model in the form of restrictions on eating and drinking for 12-18 hours a day for 29-30 days per year, namely in the month of Ramadhan. Ramadhan fasting is interesting to explore its effects on anthropometric, biochemical and oxidative stress parameters. During Ramadhan fasting, lifestyle modification and special dietary methods include changes in frequency and eating schedule, sleep patterns and increased physical activity during tarawih prayer. Several studies have revealed the effect of Ramadhan fasting on weight loss, improvement of lipid profile, pro-inflammatory cytokines (IL-1, Il-6, TNF- $\alpha$ ) and on oxidative stress markers MDA both in obese and normal individuals. Based on the characteristics of the research subjects (Table 1) the majority of subjects were male, totaling 27 people (90\%) while female subjects only 3 people (10\%). The mean age of the subjects was $27.2(23.3-31.1)$ years. This is in accordance with research conducted by Chooi et al in 2018 where globally there was an increase in the prevalence of obesity and overweight in both men and women over the age of 20 years and peaked at the age of 50 - 65 years, then decreased thereafter [1].

In this study, changes in anthropometric parameters were found before and after Ramadhan fasting (Table 2). The mean weight of the study subjects decreased from $90.8(72.2-109.4) \mathrm{kg}$ before fasting to $89.4(70.9$ - 107.9) $\mathrm{kg}$ after Ramadhan fasting. This weight loss correlates with a decrease in BMI, from a median BMI of $29.2(25.2-42.5) \mathrm{kg} / \mathrm{m} 2$ to $28.8(25.1-42.0) \mathrm{kg}$ / $\mathrm{m} 2$ after Ramadhan fasting. This is in line with a systematic review and meta-analysis by Fernando et al who reviewed 90 studies with 2947 participants. In that study it was found that Ramadhan fasting induces a temporary weight loss of $1.07-1.61 \mathrm{~kg}$ significantly $(\mathrm{p}<0.001)$ compared to the initial value. Weight loss was found to be greater in subjects with high initial BMI values. At the next follow-up after the completion of Ramadhan, weight loss was still 
found by 0.2-0.9 kg compared to the initial value [9]. Shariatpanahi et al also found a significant decrease in BMI and waist size after Ramadhan fasting ( $\mathrm{p}<0.001)$ by $3.3 \%$ and $2.7 \%$ respectively from the initial values [10]. In this study found a significant reduction in waist size, hip size and waist / hip size ratio in obese subjects. This is in line with the research of Celik et al who found a decrease in waist size $(\mathrm{p}<0.001)$, pelvic size $(\mathrm{p}=0.001)$ and hip / hip size ratio ( $\mathrm{p}$ $=0.005$ ) after Ramadhan fasting in both normal and obese individuals. But in that study, when obese subjects were grouped separately, a significant decrease was only found in waist size ( $\mathrm{p}=$ $0.041)$, whereas a decrease in hip size $(\mathrm{p}=0.063)$ and hip size ratio $(\mathrm{p}=0.102)$ were not significant [11] .

From the study it was found that the mean decrease in systolic blood pressure and diastolic blood pressure in the study subjects before and after Ramadhan fasting, but not significant ( $\mathrm{p}$ 0.475 and $\mathrm{p}$ 0.417) (Table 2). The mean systolic blood pressure before Ramadhan fasting 120.8 (111.6 - 130) and after Ramadhan fasting 119.7 (108.4 - 131) with the mean diastolic blood pressure before Ramadhan fasting was 82.4 (72.6 - 92.2) and after Ramadhan fasting 81.1 (70.6 - 91.6). This is in accordance with research conducted by Mughni, 2007 which is associated with self-control during one month of fasting. the body will be released adrenaline or epinephrine which will cause blood vessels to narrow and blood pressure will rise [12].

Lipid profiles in the subjects of this study improved with a decrease in total cholesterol $(\mathrm{p}=$ $0.001)$, an increase in HDL ( $p=0.049)$ and a significant ratio of HDL / cholesterol $(p=0.021)$ (Table 3). The increase in HDL and reduction in total cholesterol found in this study is in line with other studies. Some of these studies also found a decrease in triglycerides and LDL [4],[10],[13]-[15]. Some studies conclude that changes in lipid profile depend on changes in body weight [14].

Mazidi et al in his systematic review of studies relating to Ramadhan fasting and lipid profiles from 1984 to 2014 found that 9 studies found significant HDL increases during Ramadhan fasting. On the other hand, there are 2 studies which found a decrease in HDL during fasting [13]. Shehab et al found changes in HDL-C during Ramadhan fasting in both men and women [4]. Likewise with Shariatpanahi et al who found the mean HDL before Ramadhan fasting 41.53 \pm 5.45 rose to $46.66 \pm 5.50$ after Ramadhan fasting $(\mathrm{p}=0.002)$ [4]. HDL causes dangerous lipid movement, especially excess choleterol and from peripheral tissue to be stored in the liver. HDL also inhibits LDL aggregation enzymatically, improves blood vessel reactivity with vasodilation induced by nitric oxide production, inhibits inflammation, chemotaxis and thrombosis. HL also facilitates the transfer of macrophages out of the arterial blood vessel wall [16]. Increasing HDL through fasting or with similar dietary methods can be an additional modality for increasing HDL that is not achieved with medication alone [14].

Ramadhan fasting can reduce total cholesterol as found in this study. A systematic review by Mazidi et al found 5 studies getting a reduction in total cholesterol after Ramadhan fasting while 
2 studies found the opposite [13]. Serum cholesterol may go down a few days at a time of fasting and may increase a few days after Ramadhan fasting. Increases in cholesterol and LDL concentrations have been reported by several researchers. This increase may be related to weight loss during Ramadhan fasting. Nevertheless there are also researchers who found a decrease in cholesterol levels during Ramadhan fasting. The reduction in total cholesterol during Ramadhan fasting may be related to the frequency of large meals which are reduced to twice a day [17].

As previously explained, that cellular systems produce oxidants and tissues of the human body are affected by the balance between oxidant production and defense mechanisms in the form of antioxidants. Oxygen molecules have a high affinity for lipids. The bond between oxygen and double-chain saturated fatty acids causes a chemical reaction called lipid peroxidation. Increased lipid peroxidation is an indirect indicator of increased free radical activation. In this study found a decrease in median MDA levels before and after fasting from 4.88 (1.68-101.5) to 3.96 (0.97-92.2) with a significant $\mathrm{p}<0.001$. The decrease in MDA levels correlated significantly with the decrease in IL-6 levels after fasting $(r=0.37 ; p=0.044)$. The decrease in median MDA levels before and after Ramadhan fasting shows that Ramadhan fasting is proven to reduce lipid peroxidation and oxidative stress in people with obesity. During Ramadhan fasting, changes in eating and drinking time, reduction in eating frequency, changes in sleep patterns cause various biological changes such as the circadian distribution of body temperature, melatonin, cortisol and glycemic control. These physiological changes have been reported to modulate levels of inflammatory markers and oxidative stress in the human body. This is in line with the research of Asgary et al. In that study, MDA levels dropped significantly from 1.9 (1.39 - 2.41) to $1.73(1.35-2.11)$ after Ramadhan fasting $(\mathrm{p}=0.009)$. A decrease in MDA levels indicates a decrease in lipid peroxidation. Ramadhan fasting is assumed as one of the ways to prevent coronary heart disease where the process of atherosclerosis in the walls of the coronary arteries is triggered by the oxidation of fatty acids and LDL-C. Lipid peroxidation products (conjugated dienes) were also examined in the study but no significant changes were found

Faris et al in a meta-analysis concluded Ramadhan fasting has an effect on decreasing oxidative stress markers, although these changes are relatively small, this shows that Ramadhan fasting causes short-term protection in warding off oxidative stress and pro-inflammatory states [18] . The reduction in oxidative stress markers is in line with weight loss as found in this study. This is in line with research by Faris et al. That an increase in body weight and total body fat is associated with an increase in levels of inflammatory markers and oxidative stress in the human body, and vice versa [18]-[19]

Obesity can cause oxidative stress through activation of intracellular pathways such as nicotinamide adenine dinucleoside phosphate (NADPH), oxidase (NOX), oxidative 
phosphorylation in mitochondria, glyoxidation, protein kinase $\mathrm{C}$ and polyols. This can interfere with the regulation of adipokin synthesis such as adiponectin, visfatin, resistin, leptin, plasminogen activator inhibitors (PAI-1), TNF- $\alpha$ and IL-6. TNF- $\alpha$ and IL-6 can increase NOX activity and superoxide anion production. It seems that obesity is a link between oxidative stress and inflammation although it is not easy to confirm which one is firs. In a study conducted by Manna and Jain, 2015 reported that low levels of antioxidant molecules were found in obese subjects in line with an increase in antioxidant enzymes [20]

Although the majority of studies found a decrease in MDA, but there are also studies that contradict the results of this study. Ibarahim et al in his study did not get a significant decrease in MDA (before fasting 1.41 (1.28 - 1.72) ; after fasting 1.31 (0.8 - 1.46), p>0.05), but MDA levels in erythrocytes were found to decrease significantly (before fasting $2.62(2.39-2.85)$, after fasting $2.40(2.24-2.56), \mathrm{p}<0.05)$ [21]. In that study, there were also no changes in anthropometric parameters (body weight and BMI) and body fat mass before and after fasting. As explained above, this might explain why serum MDA levels also don't change. In addition, there are factors that influence lipid peroxidation such as the type of fat intake (saturated fat or unsaturated fat), intake of exogenous antioxidants and the production of endogenous antioxidants that are not controlled in this study (Ibrahim et al, 2008). Bahammam et al hypothesized in their research report regarding the effects of Ramadhan fasting on oxidative stress namely that the effect of Ramadhan fasting on oxidative stress would be greater if calorie and fat intake was restricted, sleep duration and physical activity were regulated. However, in the pilot study, although some factors have been regulated, it was found that MDA levels did not change significantly in both obese and non-obese individuals [22]

There were some significant differences found in body weight before and after Ramadhan fasting both in groups with tarawih less than 15 days and in the tarawih group for more than 15 days ( $\mathrm{p}=0.026$ vs $\mathrm{p}<0.001$ ). Found significant differences in body mass index before and after Ramadhan both in groups with tarawih less than 15 days and in the tarawih group more than 15 days ( $\mathrm{p}=0.033$ vs $\mathrm{p}<0.001$ ). Significant differences were found in total cholesterol before and after Ramadhan fasting both in groups with tarawih less than 15 days and in the tarawih group for more than 15 days ( $p=0.021$ vs $p=0.019)$.

Significant differences were found in MDA levels before and after Ramadhan fasting both in groups with tarawih less than 15 days and in the tarawih group for more than 15 days (p $<0.001)$. The decrease in MDA levels was found to be higher in the group with tarawih more than 15 days compared to the group with tarawih for less than 15 days ( 0.97 vs -0.71 ), but this difference was not statistically significant $(\mathrm{p}=0.171)$ (Table 3.4).

The difference in results might be influenced by differences in food type, calorie intake, level of physical activity during Ramadhan fasting, because some people decrease their physical activity during the month of Ramadhan, while others routinely perform tarawih prayers during the same 
month of Ramadhan as moderate physical activity [14]. The heterogeneity of the findings above regarding the effect of Ramadhan fasting on MDA may be influenced by various factors, including the age of the subject, geographical diversity, differences in culture and type of food, daytime temperatures, fasting duration, differences in habits during Ramadhan, calorie intake and fluid, duration and pattern of sleep and level of physical activity [18]

From this study, it was found that there was no correlation between changes in BMI with changes in lipid profiles. No correlation was found with changes in BMI with changes in total cholesterol, HDL, and HDL ( $\mathrm{p}=0.348, \mathrm{p}=0.819, \mathrm{p}=0.785$ ). Unrelated correlations can be caused by changes in the regimen / type of food consumed during Ramadhan, a decrease in activity, and several other kutural parameters. The same results were obtained in a study conducted by Ahmadinejad, Z. et al, 2006 which found no correlation between changes in cholesterol levels and changes in anthropometric factors examined. This can be due to the use of stored body fat and the synthesis of newly formed fats into the greatest source of energy in certain circumstances (Ramadhan fasting) compared to normal energy intake conditions which increase the fat element in circulation.Furthermore according to research conducted by Moore, RB, 1998, it was found that when food energy intake was near the required levels, dietary fat and blood cholesterol levels had a positive relationship [23]

Ahmadinejad, Z, et al in 2006 found a significant decrease in HDL-cholesterol and a significant increase in LDL cholesterol which is a picture of total energy intake and type of dietary fat consumed. Other studies have found elevated levels of LDL cholesterol when eating diets contain saturated fatty acids. There is research that states a decrease in LDL cholesterol is accompanied by a decrease in total blood cholesterol levels, but an increase in total cholesterol without changes in total cholesterol has been observed [23]

From this study, it was found that there was no correlation between changes in BMI and MDA changes. The study of Klop et al in (2012) and Roky et al in (2004) reported differences in habits and biologics, such as circadian rhythms, body temperature, melatonin, cortisol and blood sugar levels and also changes in sleep and wakefulness which gave different levels of serum MDA. These physiological changes are reported to modulate levels of inflammatory markers and oxidative stress in the human body [24]-[25]

Bajpai, A., in 2014 study conducted in patients with depression and controls with the same research subjects found there was a significant increase in serum MDA levels in subjects with depression when compared with healthy controls. Psychological stress is a prolonged factor causing major depression, which tends to increase MDA levels, oxidative stress, and depressive symptoms [26]

No correlation was found with changes in MDA with changes in lipid profiles in this study. Oxidative stress occurs when there is excess oxygen radicals produced by cells, which cannot 
compensate for the normal antioxidant capacity. When the concentration of reactive species cannot be controlled by internal defense mechanisms such as antioxidants (tocopherol, ascorbic acid, and glutathione) or enzymes which include oxygen radicals (catalase, peroxidase, and superoxidase dismutase, SOD), oxidative damage occurs in proteins, fats and DNA which can trigger cytotoxicity, genotoxicity, and even carcinogenesis when damaged (mutated) cells that can proliferate. This can cause no significant relationship between changes in BMI and MDA changes because when an oxidative stress occurs it will be followed by an antioxidant release [27].

Based on the researchers' assumptions, there is no correlation between changes in MDA and changes in lipid profiles due to many factors. Different food intake where the tendency for the type of fat consumed can affect MDA levels. Tarawih Prayers that can affect MDA levels given the influence of psychological factors can affect MDA levels. When fasting, fasting people become more sincere, trusting, calm and patient which according to researchers can reduce levels of oxidative stress. The strength of this study is that it is the first study to assess changes in lipid profile and MDA levels in obese patients who are fasting in Ramadhan. Limitations of this study include small sample sizes, the possibility of confounding factors that are not controlled, so that research with larger scales is needed to confirm this result.

\section{Conclusion}

There was a statistically significant decrease in MDA levels in obese patients undergoing Ramadhan fasting and a significant decrease in body weight, waist size, hip size, and statistically the waist / hip size ratio and BMI in obese patients undergoing Ramadhan fasting. There was an improved profile lipids in the form of a decrease in total cholesterol levels, an increase in HDL and a statistically significant HDL-C / TC ratio in obese patients undergoing Ramadhan fasting, while LDL levels also decrease but not statistically significant, there is a significant decrease in body weight both at tarawih $<15$ days and tarawih $>15$ days. There was a significant decrease in BMI and hip size in tarawih $<15$ days and a very significant decrease in study subjects with tarawih> 15 days. There was a significant decrease in MDA levels in research subjects with tarawih> 15 days. There is no significant correlation between changes in BMI with changes in lipid profile and MDA. There is no significant correlation in changes in BMI with changes in BMI.

\section{REFERENCES}

[1] Chooi, Y. C., Ding, C. \& Magkos, F, "The Epidemiology Of Obesity," Metabolism : Clinical And Experimental, vol. 53, pp. 66-10. 2018. 
[2] Harbuwono, D. S., Pramono, L. A., Yunir, E. \& Subekti, I, “Obesity And Central Obesity In Indonesia: Evidence From A National Health Survey,” Medical Journal Of Indonesia, vol. 27, pp.114-120. 2018

[3] Fernández-Sánchez, A., MadSrigal-Santillán, E., Bautista, M., Esquivel-Soto, J., Morales-González, Á., Esquivel-Chirino, C., et al, "Inflammation, Oxidative Stress, And Obesity,” Int. J. Mol. Sci, vol. 12, pp. 3117-3132. 2011.

[4] Shehab, A., et al, "Favorable Changes in Lipid Profile : The Effect of Fasting after Ramadhan,” PlosOne, vol. 7( issue 10) : e47615, pp. 1-4.2012.

[5] Lushchak, Strilbyska, O., Piskovatska, V., Koliada, A. \& Storey, K. B, “Intermittent Fasting," in Encyclopedia Of Medical Gerontoloy” : Elsevier, 2019, pp. 279-290. [Online]. Available: ScienceDirect.

[6] Sugondo, S.. In: Sudoyo (Ed.), Obesitas, Buku Ajar Ilmu Penyakit Dalam, vol. 2 ed. 7, Pusat Penerbitan Ipd Fkui, Jakarta, pp.2559-2569. 2014.

[7] Sherwood, L, In: Yesdelita, N (Ed), Fisiologi Manusia Dari Sel Ke Sistem, ${ }^{\text {th }}$ ed., EGC, Jakarta, p. 749-750. 2011

[8] Muliasari, A, "The Lipid Peroxidation Concentration of Hyperlipidemia Liver Rabbit which Given Hypolipodemic Compounds," Master Thesis, Biochemical Study Program, Faculty of Mathematics and Natural Sciences, Bogor Agricultural Institute, Bogo, Indonesia. 2009.

[9] Fernando, H. A., Zibellini, J., Harris, R.A. Seimon, R.V., Sainbury, A, “Effect of Ramadhan Fasting on weight and body composition in Healthy Non-Athlete Adult : a systematic review and meta-analysis," Nutrients, vol. 11, pp. 478-502, 2019.

[10] Shariatpanahi, M.V., Shariatpanahi, Z.V., Shahbazi, S., Moshtaqi, M, "Effect of Fasting with two meals on BMI and Inflamatory Markers of Metabolic Syndrome," Pakistan Journal of Biological Science, vol. 15(5), pp. 255-258, 2012.

[11] Celik, A., Saricicek, E., Saricicek, V., Sahin, E., Ozdemir, G., Bozkurt, S, et al, “ Effect of Ramadhan fasting on serum concentration of apelin-13 and new obesity indices in healthy adult men," Medical science monitor : international medical journal of experimental and clinical research, vol. 20, pp. 337-342. 2014

[12] Mughni, Abdul, “Effect of Ramadhan Fasting on Risk Factor sof Atheroscherosis Study of Lipid Profile, Blood Glucose, Blood Pressure and Body Weight," Master thesis, Univ. of Diponegoro, Semarang, Indonesia, 2007.

[13] Manna, P. \& Jain, S, “ Obesity, Oxidative Stress, Adipose Tissue Dysfunction, And The Associated Health Risks: Causes And Therapeutic Strategies," Metab Syndr Relat Disord, vol. 13, pp. 423-44, 2015. 
[14] Adam, J. M, In: Sudoyono, W. A., Setiyohadi, B., Alwi, I., Simadibrata, M. \& Setiati, S. (Eds.), Dislipidemia, Buku Ajar Ilmu Penyakit Dalam,vol.3, $5^{\text {th }}$ ed., Pusat Penerbitan Departemen Ilmu Penyakit Dalam Fkui, Jakarta, p. 1926 -1932, 2009.

[15] National Institutes Of Health, “ Overweight and Obesity Statistics,” National Institutes Of Health, The National Institute of Diabetes and Digestive and Kidney Diseases Health Information Centre, 2017. [Online]. Available: https://www.niddk.nih.gov/health-information/health-statistics/overweightobesity. [Accessed: Dec. 3, 2019].

[16] Ali, K.M., Wonnerth, A., Huber, K., Wojta, J, "Cardiovascular disease risk reduction by raising HDL cholesterol - Current therapies and future opportunities," British Journal of Pharmacology, vol. 167(6), pp. 1177-1194, 2012.

[17] Azizi, F, “Islamic Fasting And Health,” Ann Nutr Metab, vol. 56, pp. 273-282, 2010

[18] Faris, M. E. A.-I. E., Hussein, R. N., Al-Kurd, R. A. A., Al-Fararjeh, M. A., Bustanji, Y. K. \& Mohammad, M. K, "Impact Of Ramadhan Intermittent Fasting On Oxidative Stress Measured By Urinary 15-F2t-Isoprostane,” . Journal Of Nutrition And Metabolism, pp. 1-9, 2012

[19] Fernández-Sánchez, A., MadSrigal-Santillán, E., Bautista, M., Esquivel-Soto, J., Morales-González, Á., Esquivel-Chirino, C., et al., "Inflammation, Oxidative Stress, And Obesity,”.Int. J. Mol. Sci, vol. 12, pp. 3117-3132, 2011.

[20] Manna, P. \& Jain, S, “Obesity, Oxidative Stress, Adipose Tissue Dysfunction, And The Associated Health Risks: Causes And Therapeutic Strategies," Metab Syndr Relat Disord, vol. 13, pp. 423-444, 2015.

[21] Ibrahim, W. H., Habib, H. M., Jarrar, A. H. \& Baz, S. A. A, “Effect Of Ramadhan Fasting On Markers Of Oxidative Stress And Serum Biochemical Markers Of Cellular Damage In Healthy Subjects,” Ann Nutr Metab, vol. 53, 2008.

[22] Bahammam, A. S., Pandi-Perumal, S. R. \& Alzoghaibi1, M. A. 2016. The Effect Of Ramadhan Intermittent Fasting On Lipid Peroxidation In Healthy Young Men While Contro. Annals Of Thoracic Medicine, 11, 43-48.

[23] Ziaee V, Razaei M, Ahmadinejad Z, Shaikh H, Yousefi R, Yarmohammadi L, et al. The Changes of metabolic profile and weight during Ramadhan fasting," Singapore Med Journal, vol. 47(5), pp. 409-414, 2006. 
[24] Klop, B., Proctor, S. D., Mamo, J. C., Botham, K. M. \& Cabezas, M. C., "Understanding Postprandial Inflammation And Its Relationship To Lifestyle Behaviour And Metabolic Diseases,” Int. J. Vasc. Med, vol. 2012, pp. 1-11.2012.

[25] Roky, R., Houti, I., Moussamih, S., Qotbi, S. \& Aadil, N. 2004. Physiological And Chronobiological Changes During Ramadan Intermittent Fasting. Ann. Nutr. Metab, 48, 296-303.

[26] Bajpai, A., "Oxidative Stress and Major Depression," Journal Of Clinical And Diagnostic Research. Vol. 8 (12), pp. CC04 - CC07, 2014.

[27] Gagné François, "Oxidative Stress," in Biochemical ecotoxicology: principles and methods, Academic Press, 2018, 104-115. [Online] Available: Elsevier Inc. 